\title{
Implications of the Private Property Right to the Community Forest Businesses Formalization through the Certification Policy
}

\author{
Bramasto Nugroho*, Tatang Tiryana
}

Department of Forest Management, Faculty of Forestry, Bogor Agricultural University, Academic Ring Road, Campus IPB Dramaga, PO Box 168, Bogor 16680, Indonesia

Received June 7, 2013/Accepted November 13, 2013

\begin{abstract}
This study aimed to analyze the implication of formalization of community forest business efforts through mandatory timber legality certification policy. Field survey was conducted in March-April 2012 in 3 districts in Central of Java namely Blora, Wonogiri, and Wonosobo District. The results showed that community forest is mainly planting in their private owned land. It brings 2 consequences. Firstly, their willingness to manage their forest sustainably was emerged without any enforcement from external parties. Secondly, there were autonomous in decision making in their way to manage their forest such as they only planted tree species that easy to sell and valuable, they only cut their trees when they need huge money for children schooling, marriage, illness, and housing. The autonomous decision making gives also the owners (farmers) other alternatives to utilize their land otherwise planting the trees. It is mean, if the policy is decreasing the potential benefits from growing the trees, they can also convert their community forest into other business in which profitable and easy to sell their products. From those facts, it seems the formalization of community forest business through mandatory certification is not a proper policy to enhance the community forest.
\end{abstract}

Keywords: community forest, formalization, policy, private property, timber legality

\begin{abstract}
Abstrak
Penelitian ini bertujuan mengkaji implikasi formalisasi usaha hutan rakyat melalui kebijakan pewajiban sertifikasi legalitas kayu. Survei lapangan dilakukan pada Maret-April 2012 di 3 kabupaten di Provinsi Jawa Tengah yaitu Kabupaten Blora, Wonogiri, dan Wonosobo. Hasilnya menunjukkan bahwa hutan rakyat terutama ditanam di lahan milik pribadi. Kenyataan tersebut menghasilkan 2 konsekuensi. Pertama, kemauan mereka untuk mengelola hutannya secara lestari muncul dengan sendirinya tanpa paksaan dari pihak eksternal mana pun. Kedua, ada otonomi pengambilan keputusan dalam cara pengelolaan hutan mereka seperti akan menanam jenis pohon yang mudah dijual dan harganya mahal, mereka hanya akan menebang apabila memerlukan uang dalam jumlah besar untuk pendidikan anak, pernikahan anak, pengobatan, dan pembangunan rumah. Otonomi dalam pengambilan keputusan juga memberikan alternatif lain dalam memanfaatkan lahannya selain menanam pohon. Hal ini berarti apabila jika suatu kebijakan akan berakibat menurunkan keuntungan potensial dari menanam pohon maka mereka akan mengkonversi usaha hutan rakyatnya ke usaha lain yang lebih menguntungkan dan mudah menjualnya. Dari fakta tersebut, tampaknya upaya formalisasi usaha hutan rakyat melalui pewajiban sertifikasi bukanlah kebijakan yang baik untuk perkembangan hutan rakyat.
\end{abstract}

Kata kunci: formalisasi, hakmilik pribadi, hutan rakyat, kebijakan, legalitas kayu

*Correspondence author,email:bramasto2001@yahoo.co.id,tel.:+62-251-8621244

\section{Introduction}

Formalization efforts is aimed to transform community forest (CF) businesses from informal businesses, using traditional management system and unregistered into more formal management system. Formal management system was defined as applying scientific standard in forest management for promoting sustainable forest management (SFM), avoiding illegal logging, market oriented, securing the livelihoods of people dependent on it, and registered in authorized government institution. These thoughts have brought forth some policies in the development of CFs among them is implementing mandatory timber legality certification (TL-C) to CFs. This was authorized through the Minister of Forestry's Regulation (Permenhut) Number P.38/Menhut-II/2009 Jo. Number P.68/Menhut-II/2011 Jo. Number P.45/Menhut-II/2012 about the Standard and Guideline for Sustainable Production Forest Management Performance Assessment and Timber Legality Verification 
for Permit Holders or Private Forests. As with the natural production forest and plantation forest management certification schemes, the certification of CF management is a market-based instrument to promote the development of a SFM (Rametsteiner \& Simula 2003; Durst et al. 2006).

A policy will be effective when there is a relevance and conformity of the policy to the situation of the target group (Varone et al. 2006). Moreover, it must be noted that an incorrect policy intervention could in turn cause side effects that may work against the aims and purposes of the policy (Dye 2002; Dunn 2003). This is apt to happen if the policy implemented is unable to function as an incentive and on the contrary causes unnecessary burdens (disincentives) in the implementation. Therefore, all forms of formalizations that are external interventions to the established informal system need to be studied carefully. The basic research question is whether $\mathrm{CF}$ that planted in private property rights in which the owner has autonomy in the decision making is necessary to formalized through sustainable forest management (SFM) and timber legality (TL) certifications?

This study links between the characteristics of the property rights regime and the practices in forest resource management, in this case the CF. Property rights are defined as rights owned by individuals, communities, or states over a resource (asset/endowment) to manage, utilize, transfer, or even destroy the resource (Ambus et al. 2007; Alston \& Mueller 2008).

From the institution's point of view, especially related to the property right theory, CF property rights are individual/private property rights. The characteristic of private property is signified by a bundle of rights, i.e. access rights, withdrawal rights, management rights, exclusion rights, and alienation rights (Schlager \& Ostrom 1992). One of the implications of the bundle of rights on individual rights is autonomous in the decision-making.

Compared to other right regimes such as management/rental rights, and withdrawal and access rights, private property rights are the strongest rights and the more rights an individual has, the more efficient allocation is expected (Alston \& Mueller 2008; Luintel \& Chhetri 2008). In this case over use can be reduced and the will to increase long term investment and to guard the assets owned, and efficiency in trade could be increased (Ostrom 2008; Libercap 2009) when there are opportunities for profit due to availability of the market/demands, competitive prices and infrastructures (Nugroho 2010). This is understandable because strong property rights will cause all costs and losses due to flaws in resource management to be shouldered by the owner. But, on the other hand, one of the characteristics of private property right is autonomous in decision-making. It means when unsuitable policies are implemented in the effort to formalize $\mathrm{CF}$ business will in turn cause negative effects in the form of the conversion of $\mathrm{CF}$ forest businesses into other businesses which are more profitable and less troublesome. If that happens, it will not only destroy economic opportunities created by the CF business but also dissipate any social and environmental benefits generated. This study aimed to analyze the implication of formalization of community forest business efforts through mandatory timber legality certification policy.

\section{Methods}

This study uses the extensive descriptive approach: a study aimed to describe something profoundly (Irawan 2007) and relating it with relevant theories and policies (Elliot 2005). The main support theory uses is property rights theory. The policy evaluated is mandatory policy to enforce mandatory TL-C on private CF property which is stated in the Minister of Forestry's Regulation Number P.38/MenhutII/2009 Jo. Number P.68/Menhut-II/2011 Jo. Number P.45/Menhut-II/2012.

To prove that the CF was planted on the private property needs to be examined land ownership of CF. To prove that the $\mathrm{CF}$ farmers have autonomy in decision-making needs to be observed their motivation in developing $\mathrm{CF}$ and decision making in tree species selection, silvicultural treatment as well as harvesting and regeneration.

The study was conducted in the Districts of Blora, Wonogiri, and Wonosobo, Province of Central Java. Data collection was done between March and May 2012 using structured interview, focus group discussion (FGD), and field observation techniques.

The structured interview was done through questionnaires interviewed to 258 respondents who were randomly selected in the 3 districts. In Blora District were interviewed 80 respondents from 9 villages (Jatirejo, Jurangjero, Kutukan, Ngampel, Plantungan, Sendangharjo, Soko, Tempuran, and Waru). In Wonogiri Dustrict were 80 respondents from 4 villages (Ngantar, Platarejo, Selopuro, and Sumberejo). In Wonosobo District were interviewed 98 respondents from 2 villages (Besani and Jonggol Sari).

\section{Results and Discussion}

Land ownerships of community forest The respondents from Blora, Wonogiri, and Wonosobo develop CFs on private property such as lawns, gardens, fields, and paddy fields (Table 1). The status of land property is proved by Surat Keterangan Desa (village certificate), Surat Pemberitahuan Pajak Terhutang (SPPT, outstanding tax invoice), Surat Keterangan Jual Beli (certificate of trade), Sertifikat Hak Milik (property right certificate), or Surat Gadai Sertifikat (mortgage certificate). These proofs assure the status of a $\mathrm{CF}$ as a private property. Because of such clear status, the results of FGDs and interviews confirmed that generally CFs management is free from tenurial conflicts and illegal logging as commonly happened in the big-scale state forest managements, either in natural production or plantation forests management.

Motivation of community forest development Respondents motivation for developing CFs described in Figure 1. Most of the people in Blora (68\%) develop the CFs as savings for urgent house hold needs (such as their children's school and ceremony expenses). In Wonosobo, the people's motivation for developing CFs is for savings for urgent needs $(50 \%)$ and because of traditions and inheritance (49\%) for planting trees with the main reason is to fulfill urgent needs. In Wonogiri, most of the people (54\%) manage CFs as part of their tradition and family inheritance which could be used any time for urgent needs. Those economic reasons are normal as the people wish to have extra income 
Table 1 Type, area, and ownership status of CF in Blora, Wonogiri, and Wonosobo

\begin{tabular}{|c|c|c|c|c|c|c|}
\hline \multirow{2}{*}{ District } & \multicolumn{2}{|c|}{ Land use } & \multicolumn{3}{|c|}{ Property acreage (ha) } & \multirow{2}{*}{ Ownership status } \\
\hline & Type & Proportion (\%) & Average & Minimum & Maximum & \\
\hline \multirow{5}{*}{ Blora } & Lawn & 1.9 & 0.08 & 0.01 & 0.25 & Private property $(100 \%)$ \\
\hline & Garden & 0.0 & 0.00 & 0.00 & 0.00 & \\
\hline & Dry field & 91.9 & 0.61 & 0.04 & 4.10 & $\begin{array}{l}\text { Private property }(98.7 \%) \text {, } \\
\text { Cultivated land }(1.3 \%)\end{array}$ \\
\hline & Paddy field & 6.2 & 0.60 & 0.13 & 1.50 & Private property $(100 \%)$ \\
\hline & Total land & 100.0 & 0.64 & 0.04 & 4.35 & \\
\hline \multirow{5}{*}{ Wonogiri } & Lawn & 16.1 & 0.27 & 0.03 & 1.10 & Private property $(100 \%)$ \\
\hline & Garden & 1.5 & 1.00 & 1.00 & 1.00 & Private property $(100 \%)$ \\
\hline & Dry field & 79.3 & 0.77 & 0.01 & 3.00 & $\begin{array}{l}\text { Private property }(98.6 \%) \text {, } \\
\text { Cultivated land }(1.4 \%)\end{array}$ \\
\hline & Paddy field & 3.2 & 0.54 & 0.03 & 1.50 & $\begin{array}{l}\text { Private property }(66.7 \%) \text {, } \\
\text { Lease holder }(33.3 \%)\end{array}$ \\
\hline & Total land & 100.0 & 0.89 & 0.13 & 3.07 & \\
\hline \multirow{5}{*}{ Wonosobo } & Lawn & 0.0 & 0.33 & 0.02 & 1.05 & Private property $(100 \%)$ \\
\hline & Garden & 15.2 & 0.37 & 0.03 & 1.05 & Private property $(100 \%)$ \\
\hline & Dry field & 81.1 & 0.60 & 0.05 & 2.30 & $\begin{array}{l}\text { Private property }(98.8 \%) \text {, } \\
\text { Cultivated land }(1.2 \%)\end{array}$ \\
\hline & Paddy field & 3.7 & 0.30 & 0.13 & 0.48 & $\begin{array}{l}\text { Private property }(85.7 \%) \text {, } \\
\text { Cultivated land }(14.3 \%)\end{array}$ \\
\hline & Total land & 100.0 & 0.51 & 0.02 & 2.30 & \\
\hline
\end{tabular}

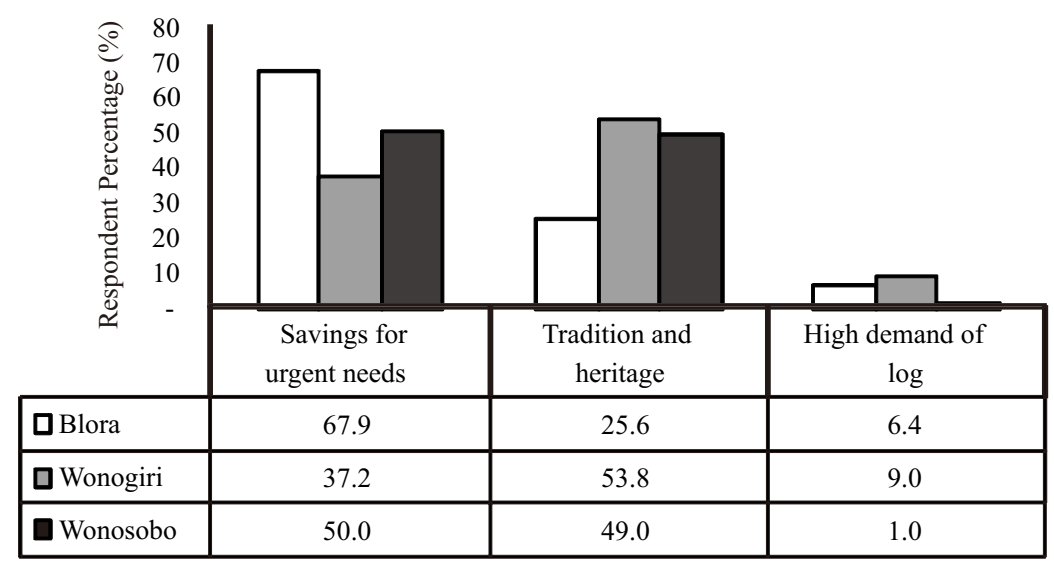

Figure 1 Respondents motivation for developing CF in Blora, Wonogiri, and Wonosobo.

besides their main income from the agricultural sector. A similar situation occurs in Finland where the economic purpose is the driving factor for forests owners to expand their forest lands (Suuriniemi et al. 2012).

Most of the people in Blora (68\%) develop the CFs as savings for urgent house hold needs (such as their children's school and ceremony expenses). In Wonosobo, the people's motivation for developing CFs is for savings for urgent needs $(50 \%)$ and because of traditions and inheritance $(49 \%)$ for planting trees with the main reason is to fulfill urgent needs. In Wonogiri, most of the people (54\%) manage CFs as part of their tradition and family inheritance which could be used any time for urgent needs. Those economic reasons are normal as the people wish to have extra income besides their main income from the agricultural sector. A similar situation occurs in Finland where the economic purpose is the driving factor for forests owners to expand their forest lands (Suuriniemi et al.2012).

Tree species selection In Blora, forest farmers commonly planted teak (Tectona grandis; 99.5\%) and mahogany (Swietenia macrophylla; $0.4 \%$ ), and a small number of fast- 
Table 2 The people of Blora, Wonogiri, and Wonosobo's considerations in selecting tree species to be cultivated

\begin{tabular}{lccc}
\hline \multirow{2}{*}{ Consideration in tree species selection } & \multicolumn{2}{c}{ Percentage (\%) of respondents' answers } \\
\cline { 2 - 4 } & Blora & Wonogiri & Wonosobo \\
\hline Seedling grants from the government & 21.1 & 1.4 & 4.2 \\
High selling prices and marketing ease & 44.7 & 38.4 & 9.2 \\
Household needs (building materials, furniture, savings) & 11.8 & 20.5 & 32.4 \\
Land compatibility & 17.1 & 38.4 & 35.9 \\
Good timber quality & 2.6 & 1.4 & 7.0 \\
Easy to plant & 0.0 & 0.0 & 4.2 \\
Species variation & 2.6 & 0.0 & 7.0 \\
\hline
\end{tabular}

Table 3 Silvicultural treatments for dominant tree kinds in the CFs in Blora, Wonogiri, and Wonosobo

\begin{tabular}{|c|c|c|c|c|c|c|c|c|c|c|c|c|c|}
\hline \multirow{2}{*}{ District } & \multirow{2}{*}{ Tree kind } & \multicolumn{2}{|c|}{ Fertilizing } & \multicolumn{2}{|c|}{ Weeding } & \multicolumn{2}{|c|}{$\begin{array}{l}\text { Replanting of } \\
\text { failures } \\
\end{array}$} & \multicolumn{2}{|c|}{ Pest control } & \multicolumn{2}{|c|}{ Prunning } & \multicolumn{2}{|c|}{ Thinning } \\
\hline & & Yes & No & Yes & No & Yes & No & Yes & No & Yes & No & Yes & No \\
\hline \multirow{2}{*}{ Blora } & Teak & 87.3 & 12.7 & 88.6 & 11.4 & 77.2 & 22.8 & 5.1 & 94.9 & 82.3 & 17.7 & 34.2 & 65.8 \\
\hline & Mahogany & 22.2 & 77.8 & 22.2 & 77.8 & 0.0 & 100.0 & 0.0 & 100.0 & 11.1 & 88.9 & 0.0 & 100.0 \\
\hline \multirow{3}{*}{ Wonogiri } & Acacia & 9.1 & 90.9 & 0.0 & 100.0 & 0.0 & 100.0 & 0.0 & 100.0 & 0.0 & 100.0 & 0.0 & 100.0 \\
\hline & Teak & 41.0 & 59.0 & 38.5 & 61.5 & 34.6 & 65.4 & 3.8 & 96.2 & 42.3 & 57.7 & 23.1 & 76.9 \\
\hline & Mahogany & 9.1 & 90.9 & 0.0 & 100.0 & 0.0 & 100.0 & 0.0 & 100.0 & 0.0 & 100.0 & 0.0 & 100.0 \\
\hline \multirow{2}{*}{ Wonosobo } & Mahogany & 68.8 & 31.3 & 53.1 & 46.9 & 9.4 & 90.6 & 3.1 & 96.9 & 28.1 & 71.9 & 3.1 & 96.9 \\
\hline & $\begin{array}{l}\text { Indonesian } \\
\text { albizia }\end{array}$ & 86.2 & 13.8 & 87.2 & 12.8 & 63.8 & 36.2 & 33.0 & 67.0 & 60.6 & 39.4 & 40.4 & 59.6 \\
\hline
\end{tabular}

growing trees such as the acacia (Acacia mangium; 0.07\%) and beechwood (Gmelina arborea; $0.02 \%$ ). This is similar to the condition in Wonogiri, where teak (50.7\%) and mahogany $(28.5 \%)$ are the most commonly planted trees in $\mathrm{CFs}$ in addition to a small number of fast-growing species such as acacia (14.5\%), albizia (Paraserianthes falcataria; $5.1 \%$ ), chinaberry (Melia azedarach; $0.7 \%$ ), beechwood $(0.5 \%)$, and indian rosewood (Dalbergia latifolia; $0.1 \%)$. In contrast, the people in Wonosobo commonly plant fastgrowing trees such as albizia (94\%), utrasum bead tree (Elaeocorpus ganitrus, 1.9\%), mahogany (0.5\%), acacia $(0.3 \%)$, indian rosewood $(0.1 \%)$, beechwood $(0.03 \%)$, large leaf rosemallow (Hibiscus macrophyllus; 0.03\%), sea hibiscus (Hibiscus tiliaceus; 0.02\%), and chinaberry $(0.01 \%)$, and a small number of slow-growing trees such as mahogany $(2.8 \%)$ and teak $(0.6 \%)$.

The highly varied species of trees in CFs is a logical consequence of the people's freedom in selecting tree species based on their individual reasons. The people of Blora generally select teak and mahogany as the main species in CFs because these trees are able to thrive on relatively unfertile soil even though they are from the slow-growing species. The people of Blora, Wonogiri, and Wonosobo's considerations in selecting tree species to be cultivated depicted in Table 2 .

Silvicultural treatment Most of the people who manage CFs in Blora (77-89\%) fertilize, weed, and patch their forests, especially for teak (Table 3 ). This is similar to what happens in Wonosobo, where most of the people (61-87\%) conduct more comprehensive silvicultural treatments (fertilizing, weeding, replanting of failures, and prunning) to albizia trees as the main species in CFs there (Table 3). The opposite is true in Wonogiri. The majority of CF owners $(>58 \%)$ do not perform any silvicultural treatments (fertilizing, weeding, replanting of failures, and prunning) to teak trees (as the main species) or other species (Table 3), they still believe more in the principle "let trees grow on their own" compared to the implementation of silvicultural treatments which could increase tree growth (Table 3 ). This is similar to what happens in Wonosobo, where most of the people (61-87\%) conduct more comprehensive silvicultural treatments (fertilizing, weeding, replanting of failures, and prunning) to albizia trees as the main species in CFs there (Table 3). The opposite is true in Wonogiri. The majority of $\mathrm{CF}$ owners $(>58 \%)$ do not perform any silvicultural treatments (fertilizing, weeding, replanting of failures, and prunning) to teak trees (as the main species) or other species (Table 3), they still believe more in the principle "let trees grow on their own" compared to the implementation of silvicultural treatments which could increase tree growth.

Harvesting and regeneration Most of the $\mathrm{CF}$ owners in Blora (84\%), Wonogori (96\%), and Wonosobo (80\%) harvest trees using the selective harvesting system and only a small 
number harvest trees using the clear-cutting system. In Blora and Wonogiri, the people harvest teak trees which are $7 \mathrm{~cm}$ in diameter and above (known as piton), whereas albizia trees in Wonosobo are harvested at the age of 5 years and a diameter of $20 \mathrm{~cm}$.

Harvesting frequency and the number of trees harvested usually correspond with family needs, a phenomenon which is known as "harvesting for needs (tebang butuh)", such as happened in Blora $(>70 \%)$, Wonogiri $(>50 \%)$, and Wonosobo $(>72 \%$ ) (Table 4$)$ to obtain cash quickly in order to fulfill urgent household needs (ceremonial expenses, children school fees, etc). Even though the price of timber is high, the people do not automatically harvest their forests if they do not have any urgent needs (Table 4).

In areas that are being harvested, the people usually regenerate (replant) with the same species of trees that were harvested because these trees have proven their suitability to the soil type, their timber quality, their marketing ease, and their high prices. Many CF owners conduct regeneration using the trubusan (coppice) method, cultivating the shoots that grow from the harvested tree stump. Besides the trubusan method, albizia tree regeneration in Wonosobo is also done by grafting.

Timber legality certification for community forest Timber legality certificates (TL-C) are certificates given to permit holders or owners of CFs which state that the permit holders or forest owners have followed timber legal standards in harvesting their forest. Based on the regulation, to obtain the TL-C they must undergo a chain of the timber legality verification standards (TLVS), which is described in Figure 3.

The main verifier for community forest TLVS is the legal land ownership/property document which is authorized by the authorities such as property ownership certificates, land title certificates, or other documents approved by the National Land Agency (Badan Pertanahan Nasional, BPN) through confirmation to the BPN and the availability of a map/sketch of the location and clear boundaries (they can be boundary markers, dikes, or fences).

Besides the mandatory TL-C from the government, there has been developed an SFM certification system which has been developed by the Lembaga Ekolabel Indonesia (LEI, the Indonesian Eco-labeling Institute) and the Forest Stewardship Council (FSC) since 1994, where both of the schemes are voluntary. At the practical level, the NGOs have been participating actively in the supervising farmer groups in achieving sustainable CFs.

Community forest formalization through timber legality certification The results of this study confirm that CFs are planted mostly on land with clear proofs of ownership in some form. Therefore, the ownership status of the CFs is private property of the owner according to the rights typology by Schlager \& Ostrom (1992) and Alston \& Mueller (2008), so the efficiency of utilization and the sustainability of management can be expected (Ostrom 2008; Libercap 2009). Efficiency of utilization is shown by the planting motivation (willingness to involve in the $\mathrm{CF}$ business) and harvesting motivation.

There are some implications of the certainty of ownership status. First, CF management is free from tenure conflict which commonly occurs in large-scale forest management on state forest, which in many cases is the main cause of unsustainable forest management. Second, the risk of illegal logging in CFs could be minimized. Clear property rights, will automatically encourage the owners to guard their resources they have developed without being prompted by anyone. This can be seen from the CF management behavior exhibited by the farmers in the 3 sample districts such as the selection of tree species which are matched to the planting location and the benefits, replanting after harvest, the implementation of the selective cutting system as a consequence of harvesting for needs, and the implementation of harvesting techniques that are quite environment-friendly. This condition happened because the benefits reaped from safeguarding their trees will be enjoyed by the owners themselves.

In contrast to forest resource management which has characteristics of common-pool resources, as with the management of state owned forest areas, they tend to easily become open access resources, especially if the resources have no managers at site level and are not strictly controlled by the government. In managing forests with the resource characteristics above, over exploitation both supported by legality (for example by business permit for timber forest product from natural forest holders) and illegal activity (for example illegal logging and forest encroachment) could happen easily. This is because the lack of adequate incentive for the permit holder to ensure sustainability (Bowers 2005).

Table 4 The motivation to harvest CFs in Blora, Wonogiri, and Wonosobo

\begin{tabular}{lrrr}
\hline \multirow{2}{*}{ Harvest motivation } & \multicolumn{3}{c}{ Proportion (\%) of respondents } \\
\cline { 2 - 4 } & Blora & Wonogiri & Wonosobo \\
\hline High timber price & 2.3 & 1.4 & 1.0 \\
Optimum harvest size/age & 0.0 & 1.4 & 0.0 \\
Developing their plantation (garden land preparation) & 0.0 & 0.0 & 1.0 \\
Building/renovating their house & 11.4 & 14.9 & 1.0 \\
Harvesting for needs & 84.1 & 81.1 & 94.8 \\
Disease attacks & 2.3 & 1.4 & 2.1 \\
\hline
\end{tabular}




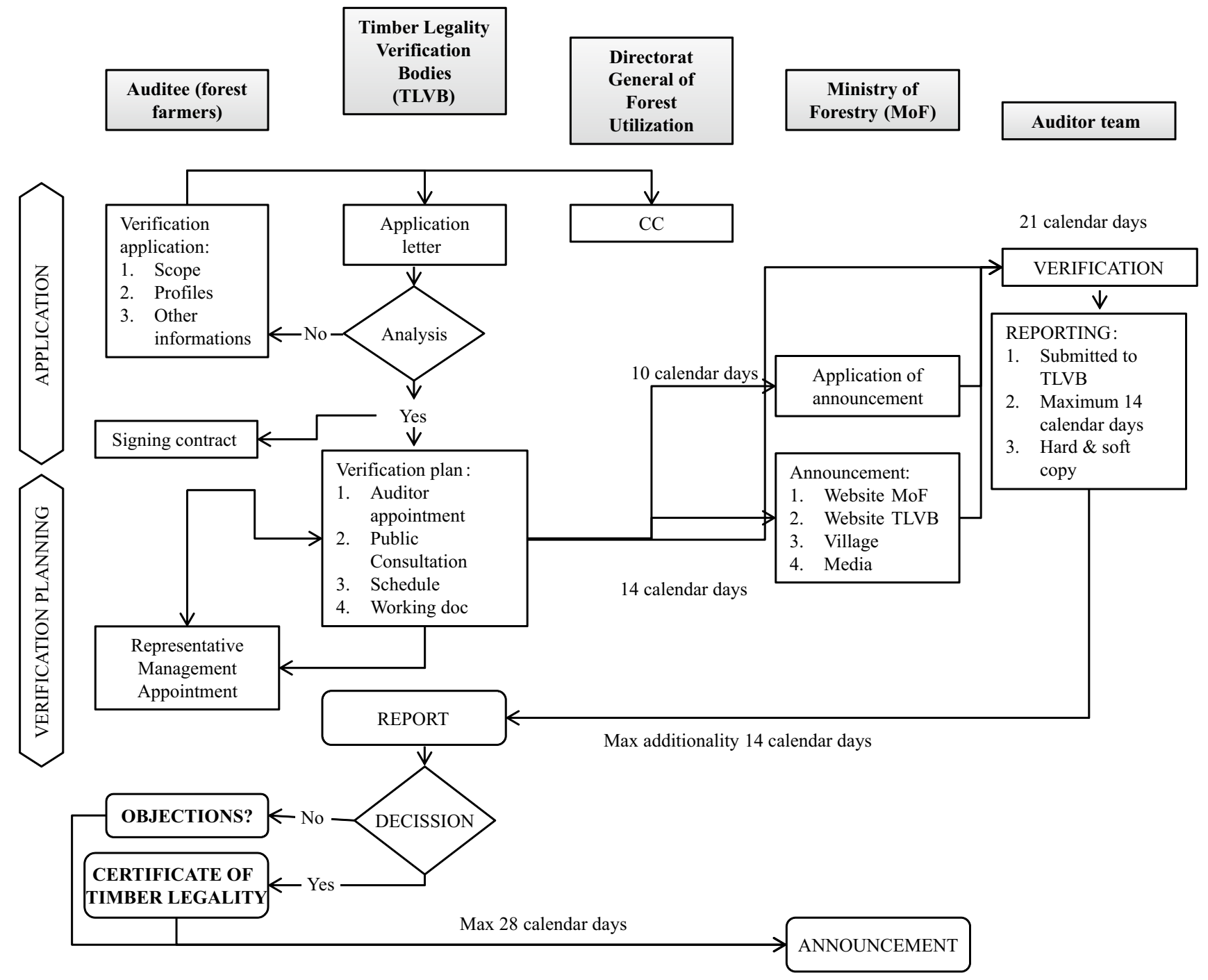

Figure 3 The steps in obtaining the TL-C.

In the economic context, this phenomenon could be considered as an externality which cannot be internalized. Therefore, the main focus in the effort to control illegal logging and to encourage SFM should be aimed at resources with common pool resource characteristics, not at private property.

From the explanation above, it is apparent that CFs formalization through the certification (TL and SFM) policy is ill-aimed. As long as there is a timber/log markets, competitive timber/log prices, infrastructures support, and property rights are ensured, even without any form of mandatory enforcement, the people will make an effort to sustain and safeguard their forest resources.

Third, there is autonomy in decisions making related to the purpose of planting which is generally to fulfill urgent household needs, the choice of trees, and the silvicultural practices applied, including harvesting and forest regeneration. This indicates it is perfectly possible for the farmers to decide not to plant forestry trees when the $\mathrm{CF}$ business is not profitable. In addition, the CF management's institutional characteristics show it is not a formal business entity. Any external intervention(s) which poses a risk of increasing transaction costs (such as certification) will be counterproductive for the development of CFs (Zhang 2001) which currently cover \pm 2.8 million ha on Java and Madura Islands and have given economic, social, and environmental benefits. The characteristic of being autonomous in decisionmaking in utilizing private property can have implications on the conversion of CFs to other uses besides as a forest. If this happens, the implementation of policies in order to formalize the business will in contrast result in the conversion of $\mathrm{CF}$ businesses into other more profitable and less troublesome businesses. So, in order to make the owners of CFs stick with the $\mathrm{CF}$ business, incentives are needed.

Form the forest management's point of view it is clear that the main motivation for planting is as savings for urgent household needs and as a tradition which has been passed down from generation to generation. Harvesting for needs indicate that the farmers will harvest if they have urgent needs for a large amount of cash, such as for circumcision 
ceremonies, weddings, and children' school fees. This means that even if the trees their own are ready to harvest, they will refuse to harvest except when they have urgent need. On the other hand, they would harvest their trees even though they are not yet ready to harvest if they have urgent needs.

The harvesting for needs phenomenon indicates that as long as urgent needs are fulfilled, harvesting of immature trees can be avoided. Fulfilling urgent needs can be done by developing a collective action through the strengthening of farmers' groups which will enable the members to lend and borrow among themselves. Another way is to provide a micro-financing institution which could fund urgent household needs by giving "harvest postponement credit (kredit tunda tebang)". Therefore, the form of formalization which could solve actual CF management problems is by developing a collective action and/or providing a microfinancing institution which could overcome the harvesting for needs problem.

Harvesting for needs in the management of CFs also indicate that some of the farmers' needs actually rely on the presence/existence of the CFs they own. This dependence will make the existence of CFs psychologically valuable for the farmers. This psychological situation will encourage the farmers to always strive to sustain and safeguard their forests from any threats, including illegal logging.

As a market-based instrument, certification is often associated to hopes to increase the price of timber (called premium price) and the market access of certified timber (Rametsteiner \& Simula 2003). If the increase in the price of timber and the market access of certified timber can be materialized, then formalization through certification will increase the farmers' income. But if the benefits of certification cannot be materialized, then the certification policy will only increase the farmers' transaction cost and will in turn decrease the CF business profit level.

The hopes of increasing the price of certified timber appeared among the CF farmers in Selopuro and Sumberejo Villages, Wonogiri District, when they began the process of managing CFs based on the principles of SFM. However, after they had succeeded in obtaining the Community Based Sustainable Forest Management (CBSFM) certificate from the LEI in 2004, the farmers felt disappointed because there was no premium price of the LEI certified timber. While in fact the farmers were burdened by a fairly large amount of extra costs for the CBSFM certification. This condition will often dampen the farmers' enthusiasm for sustainable $\mathrm{CF}$ management.

The expectation for a premium price also arose among the $\mathrm{CF}$ farmers of Wonosobo and Blora when the government began the campaign of the TL-C in 2009. In order to support the implementation of the TL-C, the District Forestry Agency and the NGO ARUPA (Alliance of Volunteers for Nature Preservation) helped facilitate the founding of some Forest Farmers' Group Union (Gapoktanhut) or CF Owner Association (APHR) such as Gapoktanhut Jati Mustika in Blora and APHR Joko Madu in Wonosobo as a form of CF management business unit formalization. Gapoktanhut Jati Mustika and APHR Joko Madu succeeded in obtaining the TL-C in 2011 (valid to 2014). But, after they had obtained the certificate, the farmers felt deeply disappointed because of the lack of premium prices for the timber traded. Those situations also happened in Canada regarding to the forest certification for Aboriginal group. Tikina et al. (2010) concluded that forest certification must clearly become a beneficial proposition, in terms of monetary and nonmonetary benefits, before Aboriginal groups adopt it. Supporting Aboriginal obtaining a price premium for them could be a possible way to change the situation.

Even worse, the farmers in Blora and Wonosobo were faced with the lack of funds to perform the TL-C surveillance process which at the beginning had to be conducted annually (Permenhut P.38/Menhut-II/2009) and now every 2 years (Permenhut P.45/Menhut-II/2012). According to the FGDs is approximately IDR 50 million ( \pm USD 5,265 using 1 USD = IDR 9,500 exchange rate at 2012) for obtaining the TL-C and around IDR 25 million ( \pm USD 2,630 using 1 USD = IDR 9,500 exchange rate at 2012) for the surveillance.

Indeed, the farmers joined in the farmers' groups could improve CF management practices. Indeed, the supervision by NGOs (PERSEPSI and ARUPA) in obtaining the CBSFM certification (in Wonogiri) and TL-C (in Blora and Wonosobo) in the frame of the aid program from the donor Lembaga Ekolabel Indonesia (LEI) and Multistakeholders Forestry Program (MFP) had positive effects in the form of an increase in the people's insight and knowledge of $\mathrm{CF}$ management practices. For example, the $\mathrm{CF}$ farmers of Wonogiri now understand that measurements of tree diameter should be taken at $1.3 \mathrm{~m}$ above the ground (diameter at breast height). Knowledge how to measure tree diameter is useful for the farmers so that they can avoid the cheating practices of middlemen who measure the diameter higher than $1.3 \mathrm{~m}$ above the ground in order to get smaller volume estimation.

However, the improvements in the management system and the increase in the people's knowledge are basically a result of mentoring activities conducted by the NOGs, not because of the TL-C policy. This is because the TL Verification Body (TLVB) was not meant to mentoring farmers but instead to verify timber legality. In the case of the three sample districts, mentoring was conducted as a result of aid projects from LEI and MFP. Therefore, with or without the TL-C policy, mentoring is deemed very beneficial for improving and increasing the farmers' CF management knowledge (Tyler et al. 2007). In addition, it can be said that in general the CF management practices in the three districts still need improvement through outreach programs and mentoring programs by the forestry agency or other related institutions.

\section{Conclusion}

CFs are located on land that has a private property status. Therefore, internalization of externalities could be easily done, meaning that all the losses caused by mismanagement will be shouldered by the owners themselves; including negligence in safeguarding their forest resources. This condition will encourage the owners to sustain and safeguard their forest from all threats, including illegal logging. In order to sustain their resources, the farmers select the species of trees to be planted according to the location and uses, replant harvested areas, implement selective cutting system as a consequence of harvesting for needs, and implement fairly 
environment-friendly harvesting practices. These forest management practices are the product of the farmers' interaction with their biophysical and social environment (autonomy in decision-making). Formalization through mandatory certification with the purpose to ensure forest sustainability and prevent illegal logging seems to be excessive efforts if it is implemented in the CF businesses which are mostly planted on private property. The purpose to increase the farmers' income through premium prices in truth has not been accomplished and has disappointed the $\mathrm{CF}$ owners. An inappropriate policy intervention might have counterproductive effects on the development of CFs as a consequence of decision-making autonomy in the utilization of private property, the conversion of CFs to other businesses that are more profitable and less complicated in the administration of the product trade.

\section{Recommendation}

Formalization efforts through policy intervention should be aimed at decreasing transaction costs, abolishing policies that complicate the timber trade system (certificate of timber origin, TL, and SFM certification), increasing the economic benefits of the CF business, and providing both direct and indirect incentives to safeguard and encourage the people's interest in investing in the CF business. In addition, the formalization that the people need is the form of formalization that can overcome the "harvesting for needs" problem through the "harvest postponement credit" by a formal institution (such as a cooperative, farmers' group, etc.). Mentoring activities of the $\mathrm{CF}$ farmers in the study locations was very beneficial for the improvement of the people's management system and knowledge. However, the mentoring was not a result of the implementation of the TL or SFM Certification in the TLVS policy guidelines but a result of aid from donors to support the certification. Therefore, whether or not there is a certification, mentoring is still needed.

\section{Acknowledgement}

This study was a part of the "PRO-FORMAL: Policy and regulatory options to recognize and better integrate the domestic timber sector in tropical countries" study, an international collaborative study between CIFOR and PSP3 IPB. Deep gratitude is directed to NI Wianti, Marwoto, M. Sidiq, Nining Assyh, Frida Yulianti, and Nuva who have helped in the field data collection for this study.

\section{References}

Alston LJ, Mueller B. 2008. Property Rights and the State. In: Ménard C, Shirley MM, editors. Handbook of New Institutional Economics. Heidelberg: Springer-Verlag Berlin Heidelberg. pp 573-590. http://dx.doi.org/ $\underline{10.1007 / 978-3-540-69305-523}$.

Ambus L, Davis-Case D, Tyler S. 2007. Big expectations for small forest tenures in British Columbia. BC Journal of Ecosystems and Management 8(2):46-57.

Bowers J. 2005. Instrument choice for sustainable development: an application to the forestry sector. Forest
Policy and Economics 7(2005):97-107. http://dx.doi. org/10.1016/S1389-9341(03)00015-7.

Dunn WN. 2003. Pengantar Analisis Kebijakan Publik. Wibawa S, Asitadani D, Hadna AH, Purwanto EA, translator. Jogjakarta: Gadjah Mada University Press. Translated from Public Policy Analysis: An Introduction.

Durst PB, Mckenzie PJ, Brown CL, Appanah S. 2006. Challenges facing certification and eco-labelling of forest products in developing countries. International Forestry Review 8(2):193-200. http://dx.doi.org/ $\underline{10.1505 / \text { ifor.8.2.193. }}$.

Dye TR. 2002. Understanding Public Policy. USA: PrenticeHall.

Elliott J. 2005. Using Narrative in Social Research: Qualitative and Quantitative Approaches. London: SAGE Publications.

Irawan P. 2007. Penelitian Kualitatif dan Kuantitatif untuk Ilmu-ilmu Sosial. Jakarta: DIA Fisip UI Press.

Libecap GD. 2009. The tragedy of the commons: property rights and markets as solutions to resource and environmental problems. The Australian Journal of Agricultural and Resource Economics 53:129-144. http://dx.doi.org/10.1111/j.1467-8489.2007.00425.x.

Luintel H, Chhetri RB. 2008. Understanding tenure security in community forestry. Journal of Forest and Livelihood $7(1): 1-5$

Nugroho B. 2010. Institutional development for community forest revolving fund. Jurnal Manajemen Hutan Tropika 16(3):118-125.

Ostrom E. 2008. Institutions and the environment. Journal Compilation of Institute of Economic Affairs 28(3): 24-31.

Rametsteiner E, Simula M. 2003. Forest certification-an instrument to promote sustainableforest management? Journal of Environmental Management 67:87-98. http://dx.doi.org/10.1016/S0301-4797(02)00191-3.

Schlager E, Ostrom E. 1992. Property-rights regimes and natural resources: a conceptual analysis. Land Economics 68(3):249-262. http://dx.doi.org/10.2307/ $\underline{3146375 .}$.

Suuriniemi I, Matero J, Hanninen H, Uusivuori J. 2012. Factors affecting enlargment of family forest holdings. Silva Fennica 46: 253-266.

Tikina AV, Innes JL, Trosper RL, Larson BC. 2010. Aboriginal peoples and forest certification: a review of the canadian situation. Ecology and Society 15(3): 33-52

Tyler S, Ambus L, Davis-Case D. 2007. Governance and management of small forest tenures in British Columbia. BC Journal of Ecosystems and Management 8(2):67-78. 
Varone F, Benoit R, Axel M. 2006. A new methode for policy evaluation? Longstanding challenges and the possibilities of qualitative comparative analysis (QCA). In: Rihoux B, Grimm H, editor. Innovative Comparative Methods for Policy Analysis: Beyond the Quantitative-Qualitative Divide. New York, USA Springer Science Business Media
Inc.; pp. 213-236. http://dx.doi.org/10.1007/0-38728829-5 10.

Zhang Y. 2001. Economics of transaction costs saving forestry. Ecological Economics 36 (2001):197-204. http://dx.doi.org/10.1016/S0921-8009(00)00228-7. 